\title{
Miocene Planktonic Foraminifera of Calcareous Sandstone Unit in Pamutuan Formation West Java, Indonesia
}

\author{
Gabriela C. N. Gaspersz ${ }^{1 *}$, Vijaya Isnaniawardhani ${ }^{2}$, Santi Dwi Pratiwi ${ }^{2}$ \\ and Lilian C. Rieuwpassa ${ }^{1}$ \\ ${ }^{I}$ Undergraduate Program of Geological Engineering, Universitas Padjadjaran, Bandung, Jl. Raya Bandung- \\ Sumedang Km.21 Jatinangor, Sumedang 45363, West Java, Indonesia \\ ${ }^{2}$ Department of Geoscience, Faculty of Geological Engineering, Universitas Padjadjaran, Bandung, Jl. Raya \\ Bandung-Sumedang Km.21 Jatinangor, Sumedang 45363, West Java, Indonesia
}

\begin{abstract}
The research area is located in Cigugur, Jadimulya, and Bangunkarya, Pangandaran, West Java. This research is focus on identification and determination the age of calcareous sandstone unit based on foraminifera assemblages. In the research area, the calcareous sandstone unit included in Pamutuan Formation. Based on previous research, regionally the age of Pamutuan Formation is Middle Miocene which deposited with many energy changes and related to the effect of sea level changes. The research method started with literature study followed by field observation by using spotting sampling method, preparation process, and laboratory analysis. Preparation process of foraminifera planktonic performed against six samples of rock by using the method of residues. Samples of foraminifera planktonic are analyzed using binocular microscope and determining the age range of the foraminifera planktonic species based on Bolli classification. The calcareous sandstone unit consists of massive sandstones. The foraminifera planktonic such as Globorotalia opima nana, Catappsydrax dissimilis, Globorotalia obesa, Globigerinoides ruber, Globorotalia mayeri, Sphaerodinellopsis disjuncta, Globigerinoides obliquus, and Globorotalia fohsi peripheroronda are identified in samples. Based on the presence of those foraminifera planktonic marker species, conclude that the calcareous sandstone unit in Pamutuan Formation is indicated to be deposited in the relative age range of N6 to N10 or Early Miocene to Middle Miocene.
\end{abstract}

Keywords: Foraminifera planktonic, Pamutuan formation, Early Miocene, Middle Miocene.

\section{Introduction}

Micropaleontology study is a study that is associated with the remnants of organism in the form of fossil sized micro are usually referred to as microfossils. Assessment is typically used to identify the age of a rock, the reconstruction of the environment sedimentation, and its application in determining paleoecology, paleoceanography, and paleoclimatology. Foraminifera is one of the types of microfossils, which the general size of $0,1 \mathrm{~mm}$ to less over $1 \mathrm{~mm}$. This is one of the types of microfossils which are usually used in micropaleontology study particularly in the determination of the age and reconstruction environment deposition of rocks based on their abundance in sedimentary rock. Characteristics common foraminifera are organisms aquatic unicellular who have one or more rooms are separated one each other by septa and are penetrated by many holes fine (foramen). Foramnifera planktonic is one of the type of foraminifera that live in pelagic zone. The important role of this foraminifera planktonic is as determinant of the age of rock, as a reference fossil and sometime also a determinant the depositional environment.

Based on the study of geological regional, Pamutuan Formation arranged on gray-greenish sandstone lined well, calcarenite, marl, tuff, mudstone, and limestone. Foraminifera were found at the formation of this among others Globocasidulina sp., Amphistegina sp., Globoquadrina altispira (Chushman \& Jarvis), Globigerinoides immaturus LEROY, and Globorotalia mayeri (Chushman \& Ellisor) indicate that the formation is deposited at 
the age of Middle Miocene and the environment depositional marine is shallow until open (Van Bemmelen 1949; Soekamto 1975; M. Mudjito GL Samuel 1975; Udin Adinegoro 1976; and S. Martodjojo 1984).

In this study, we carried out detailed analysis and observations about the age of calcareous sandstone unit in Pamutuan Formation. To determine the age of the calcareous sandstone unit Pamutuan Formation, we used planktonic foraminifera analysis.

\section{Methodology}

This study uses data collection techniques of qualitative and quantitative consisting of : study literature, field observations by using spotting sampling method, the preparation process of samples, and laboratory analysis in terms of this determination foraminifera planktonic using a binocular microscope. Field observation is done with review directly outcrop of rock, description in megascopic, sampling and take a photos in 6 (six) location of observation were scattered in Cigugur, Jadimulya, and Bangunkarya, Pangandaran, West Java, Indonesia (Fig. 1).

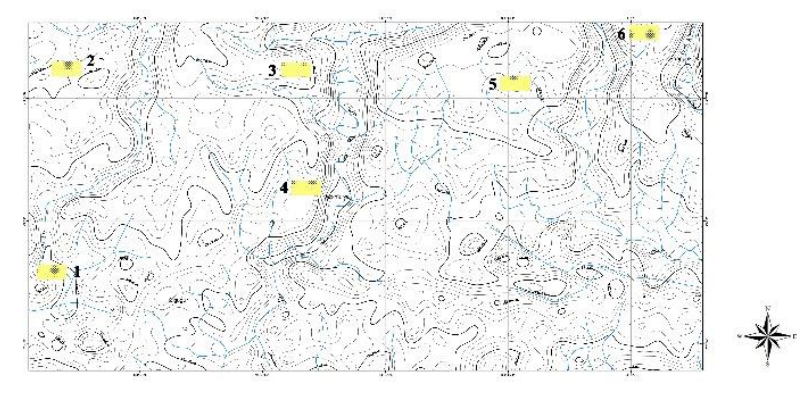

Fig. 1 Map of sampling location

Furthermore, the process of preparation of foraminifera planktonic performed against 6 (six) samples of rock by using residues method. After the preparation is done, the analysis process of foraminfera planktonic using a binocular microscope is carried out and determining the age range of the foraminifera planktonic species based on classification of Bolli (1985).

Observation field phase lasts for one week starting from 1 March 2020 until 7 March 2020 followed by preparation stage, analysis stage until determination of age range which lasted for approximately over one month starting from 26 June 2020 until 31 July 2020.

\section{Results and Discussion}

Megascopically, the lithology of the sandstone in the calcareous sandstone unit has a fresh grayish white to light gray color and a weathered yellow-brown to blackish color. Has a grain size of fine sand (1/4 mm $-1 / 8 \mathrm{~mm})$ to very fine sand (1/8 mm $-1 / 16 \mathrm{~mm})$, closed packing, fine sorting, sub-rounded to rounded grain shape, and carbonate. The sedimentary structures contained in the outcrops are massive and the brittle is hardness (Fig. 2). 


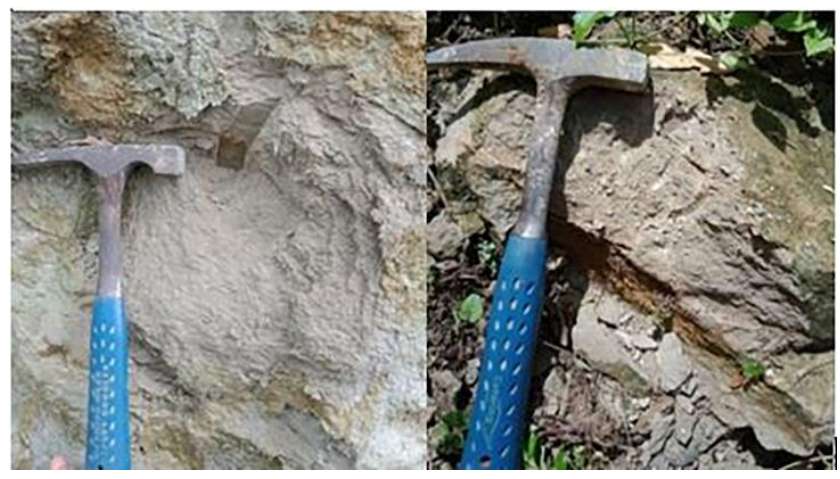

Fig. 2 Outcrop of sandstone lithology

By microscopic, thin section sandstone is composed of 6-\% matrix, and 38\% of the fragments with the type of clays and carbonate mineral (Fig. 3). The morphology of this rock is rounded. The degree of roundness includes medium sphericity. Disaggregated medium and matrix supported, there are fossils of foraminifera planktonic and algae. The components consist of 20\% k-feldspar, 5\% quartz, 3\% opaque mineral, and $10 \%$ fossil fragments. There are a few ooids with brownish color, round shape, and high relief (Tandean 2019).

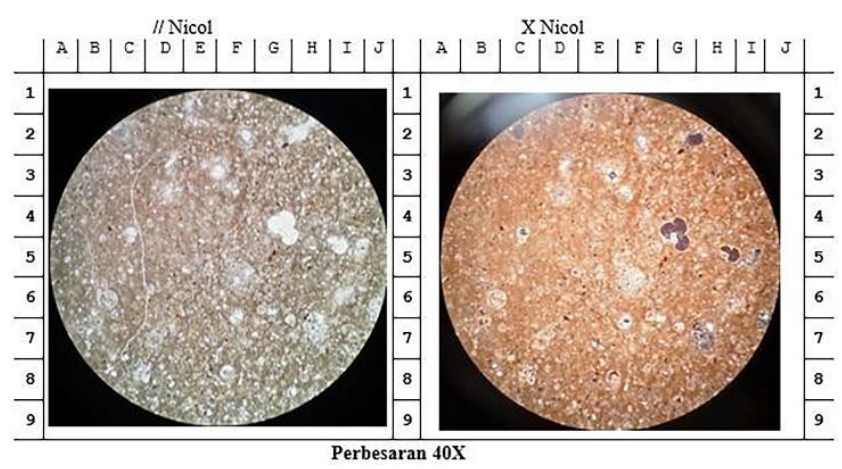

Fig. 3 Thin section of sandstone

Source (Tandean 2019)

Based on the analysis of foraminifera planktonic at 6 (six) samples of rock that found 8 (eight) species of foraminifera planktonic as a determinant of age of calcareous sandstone unit Pamutuan Formation, as follows :

\section{Globorotalia opima nana}

Having a calcareous wall, cavities and surfaces are perforated smooth and has a room that is round about 10 (ten) rooms (Fig. 4). The shell of the spiral-shaped radial. Have umbilicus narrow and inside as well as opening the arch low, on the edge or lip often appears interiomarginal, umbilical-extraumbilical, coiled in random, with the size of most large holotype $(0,33 \mathrm{~mm})$. Age range N3 to N6. 


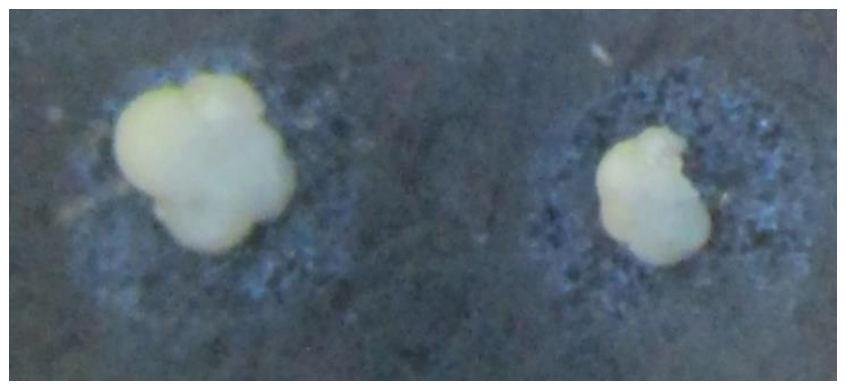

Fig. 4 Globorotalia opima nana species

\section{Catappsydrax dissimilis}

The trochospiral test is weak moderate, the spiral side is slightly convex, the umbilical side strengthens the convex, the axial periphery has a round and wide shape. The walls are full of holes and the surface is mottled. The room is spherical, the last room is slightly sideways solid or thin and flat, composed of 3 (three) rounds and 4 (four) rounds of the last rooms increasing in size. Suture in the spiral twisted up slightly bent, the side part in the umbilical radial. Aperture is the primary aperture, interiomarginal, umbilical, within the end of the growth that is covered by and umbilical bulla, with 2-4 garnish infralaminal apertures (Fig. 5). Age range P/18 to N6.

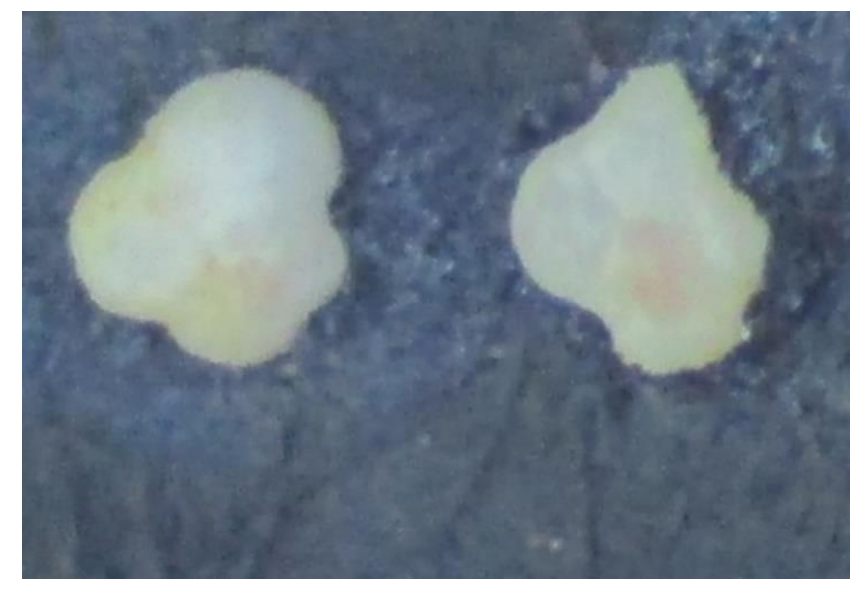

Fig 5. Catappsydrax dissimilis species

\section{Globorotalia obesa}

Has a shell shaped trochospiral, form rooms spherical with the size of the change in each room, and the rooms are located in the round of last had a change of shape drastic. The aperture is curved and does not have a shell lip (Fig. 6). Age range N5 to N15. 


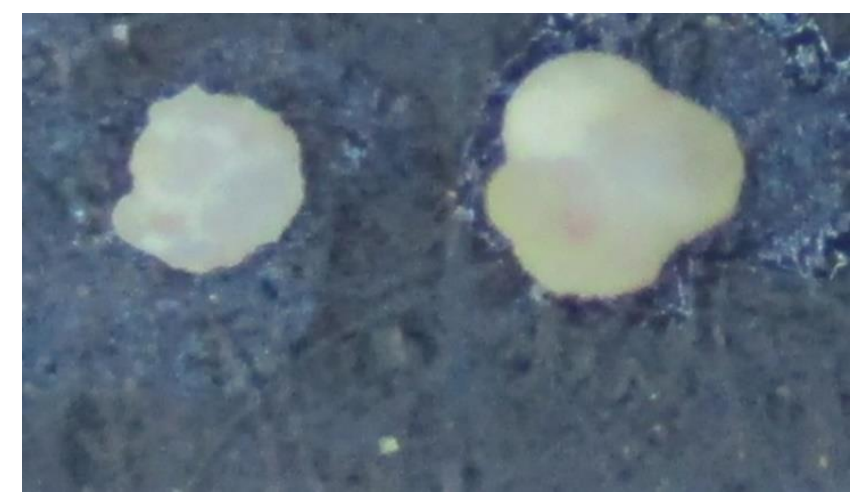

Fig. 6 Globorotalia obesa species

\section{Globigerinoides ruber}

Having shells trochospiral, the equatorial periphery lobulated, rounded, wall shells in general the surface porous and slightly, arranged over three to four rounds, three rooms on lap final size is increased by slowly, suture on the side of spiral sub radial to radial, and slightly curved. The interiomarginal, umbilicus, and secondary sutural aperture are opposite to the primary aperture (Fig. 7). Age range N5 to N13.

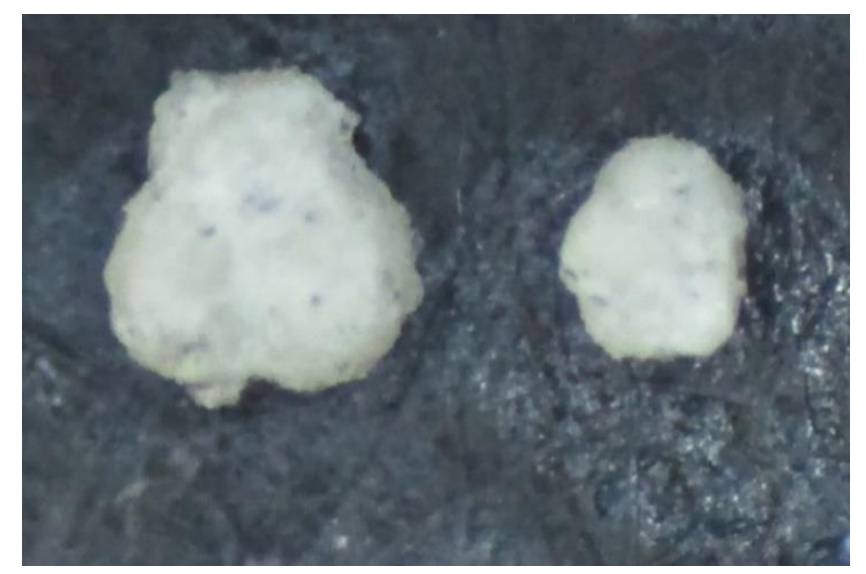

Fig. 7 Globigerinoides ruber species

\section{Globorotalia mayeri}

It has a trochospiral shell, compression and rhomboid chambers which are composed of 3 (three) rounds, the fourth and fifth chambers are at the end of the rotation, the aperture is anteriomarginal, and has extraumbilical, and random circular (Fig. 8). Age range N3 to N14. 


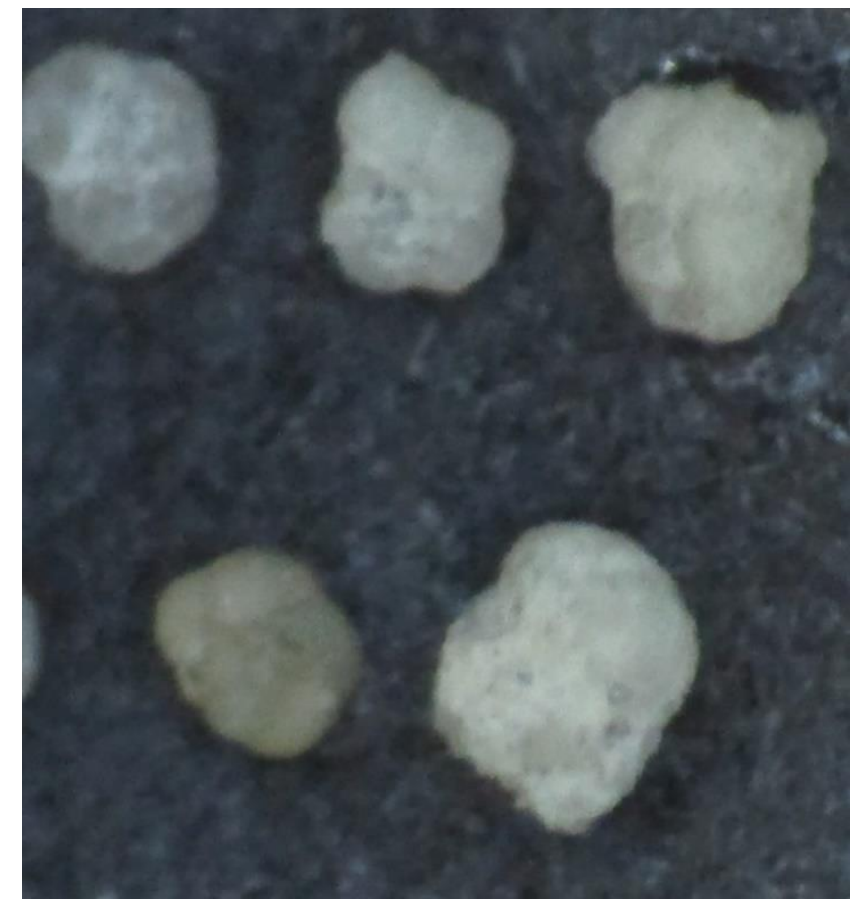

Fig. 8 Globorotalia mayeri species

\section{Sphaeroidinellopsis disjuncta}

Having shells trochospiral, compact, equatorial periphery somewhat lobulated, axial periphery rounded, wall primer coarsely perforate, covered by a layer of a second, the surface smooth and looks glassy, subglobular room, suture indistinct, radial somewhat depressed (Fig. 9). Age range N9 to N17.

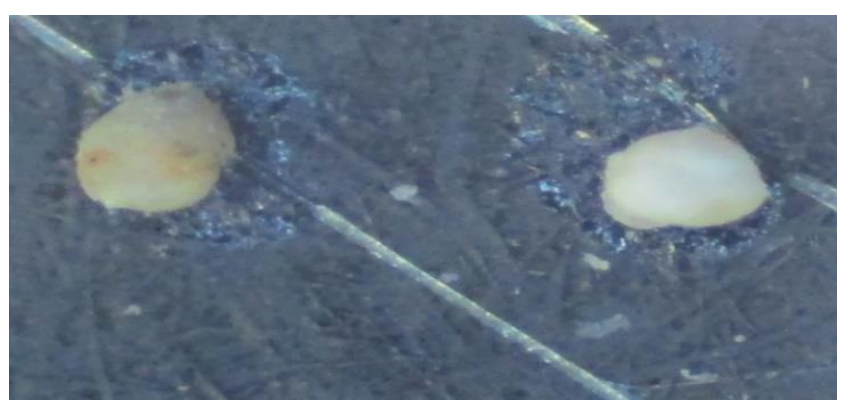

Fig. 9 Sphaeroidinellopsis disjuncta species

\section{Globigerinoides obliquus}

Has the last room which is oblique shape. The primary interiomarginal umbilical aperture, strongly curved. Most small from room last showing an aperture secondary that opposite with aperture primer (Fig. 10). Age range $\mathrm{N} 8$ to $\mathrm{N} 9$. 


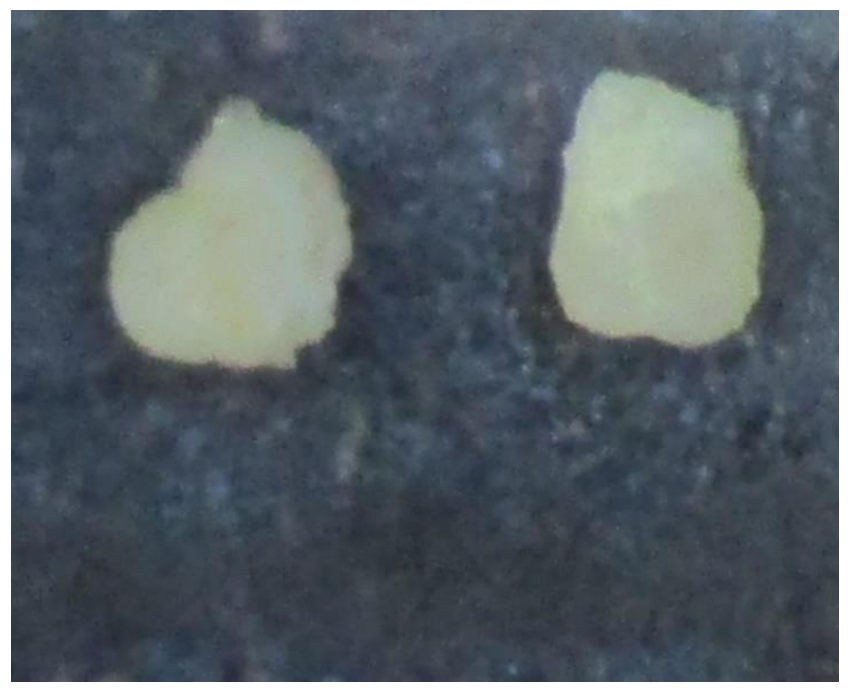

Fig. 10 Globigerinoides obliquus species

\section{Globorotalia fohsi peripheroronda}

Has a trochospiral low room, biconvex are balanced, the periphery of the equator somewhat lobulated, peripheral axial angled taper with a keel that is clear. The walls are porous, the surface of the initial room rugose then smooth. Rooms are depressed strong, composed of three rounds, 5 (five)-6 (six) rooms of rounds last enlarged by quickly (Fig. 11). Age range N6 to N10.

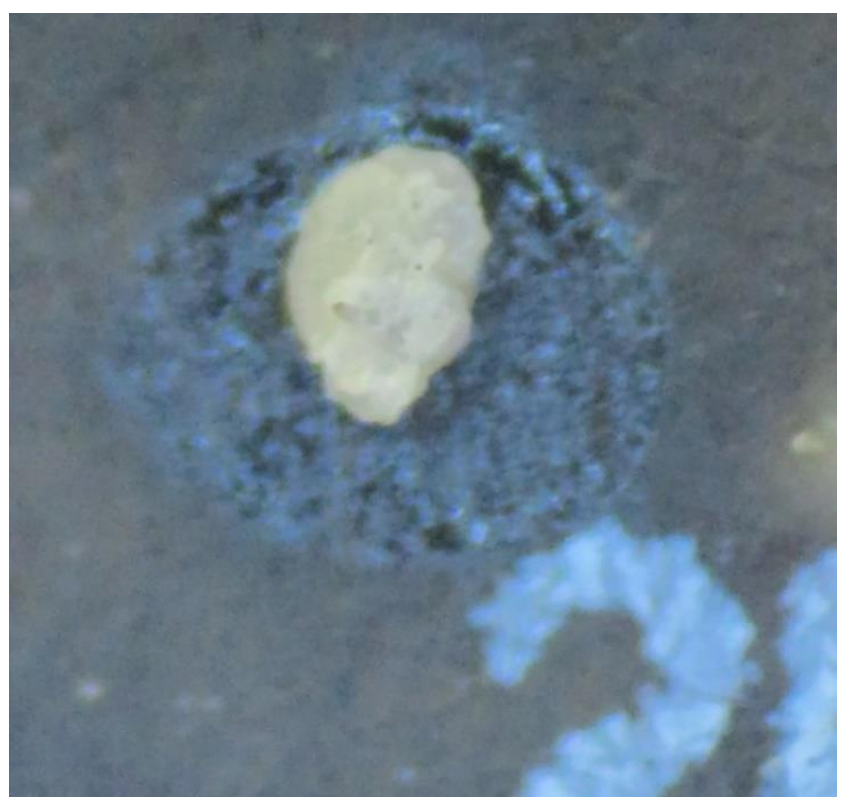

Fig. 11 Globorotalia fohsi peripheroronda species

Based on the age range of the species mentioned, it can be determined that the age range of calcareous sandstone unit Pamutuan Formation is N6 to N10 or Early Miocene to Middle Miocene (Table 1). 
Table. 1 Determination the age of calcareous sandstone unit Pamutuan Formation based on the age range of foraminifera planktonic species

\begin{tabular}{|c|c|c|c|c|c|c|c|c|c|c|c|c|c|c|c|c|c|c|c|c|c|c|c|}
\hline \multirow{3}{*}{ NO. } & \multirow{3}{*}{$\begin{array}{l}\text { Age } \\
\text { Foraminifera } \\
\text { Planktonic }\end{array}$} & \multirow{2}{*}{\multicolumn{4}{|c|}{ Oligocene }} & \multicolumn{15}{|c|}{ MIOCENE } & \multirow{2}{*}{\multicolumn{3}{|c|}{$\begin{array}{l}\text { PLIO } \\
\text { CENE }\end{array}$}} \\
\hline & & & & & & \multicolumn{5}{|l|}{$\mathrm{E}$} & \multicolumn{7}{|l|}{$\mathrm{M}$} & \multicolumn{3}{|c|}{$\mathrm{L}$} & & & \\
\hline & & $\begin{array}{l}8 \\
/ \\
1 \\
9\end{array}$ & $\begin{array}{l}\mathrm{N} \\
1\end{array}$ & $\begin{array}{l}\mathrm{N} \\
2\end{array}$ & $\begin{array}{l}N \\
3\end{array}$ & $\begin{array}{l}N \\
4\end{array}$ & $\begin{array}{l}N \\
5\end{array}$ & $\begin{array}{l}N \\
6\end{array}$ & $\begin{array}{l}\mathrm{N} \\
7\end{array}$ & $\begin{array}{l}N \\
8\end{array}$ & $\begin{array}{l}N \\
9\end{array}$ & $\begin{array}{c}\mathrm{N} \\
1 \\
0\end{array}$ & $\begin{array}{c}\mathrm{N} \\
1 \\
1\end{array}$ & $\begin{array}{l}N \\
1 \\
2\end{array}$ & $\begin{array}{l}\mathrm{N} \\
1 \\
3\end{array}$ & $\begin{array}{l}\mathrm{N} \\
1 \\
4\end{array}$ & $\begin{array}{c}\mathrm{N} \\
1 \\
5\end{array}$ & $\begin{array}{c}\mathrm{N} \\
1 \\
6\end{array}$ & $\begin{array}{l}N \\
1 \\
7\end{array}$ & $\begin{array}{l}\mathrm{N} \\
1 \\
8\end{array}$ & $\begin{array}{l}\mathrm{N} \\
1 \\
9\end{array}$ & $\begin{array}{l}\mathrm{N} \\
2 \\
0\end{array}$ & $\begin{array}{l}\mathrm{N} \\
2 \\
1\end{array}$ \\
\hline 1. & $\begin{array}{l}\text { Globorotalia opima } \\
\text { nana }\end{array}$ & & & & & & & & & & & & & & & & & & & & & & \\
\hline 2. & $\begin{array}{l}\text { Catappsydrax } \\
\text { dissimilis }\end{array}$ & & & & & & & & & & & & & & & & & & & & & & \\
\hline 3. & Globorotalia obesa & & & & & & & & & & & & & & & & & & & & & & \\
\hline 4. & Globigerinoides ruber & & & & & & & & & & & & & & & & & & & & & & \\
\hline 5. & Globorotalia mayeri & & & & & & & & & & & & & & & & & & & & & & \\
\hline 6. & $\begin{array}{l}\text { Sphaerodinellopsis } \\
\text { disjuncta }\end{array}$ & & & & & & & & & & & & & & & & & & & & & & \\
\hline 7. & $\begin{array}{l}\text { Globigerinoides } \\
\text { obliquus }\end{array}$ & & & & & & & & & & & & & & & & & & & & & & \\
\hline 8. & $\begin{array}{l}\text { Globorotalia fohsi } \\
\text { peripheroronda }\end{array}$ & & & & & & & & & & & & & & & & & & & & & & \\
\hline
\end{tabular}

\section{Conclusion}

Based on the results of the analysis of the age range of species Globorotalia opima nana, Catappsydrax dissimilis, Globorotalia obesa, Globigerinoides ruber, Globorotalia mayeri, Sphaerodinellopsis disjuncta, Globigerinoides obliquus, and Globorotalia fohsi peripheroronda, it can be concluded that the calcareous sandstone unit Pamutuan Formation deposited in the relative age range of N6 to N10 or Early Miocene to Middle Miocene.

\section{Recommendation}

The analysis result of the age range of calcareous sandstone unit Pamutuan Formation in this micropaleontology study is expected to be useful additional knowledge for the research area. Howeverm this study still requires additional research to become a complete package of micropaleontology studies, for example research on the determination of the depositional environment of this Pamutuan Formation especially calcareous sandstone unit. For that, we hope there will be further research that can discuss this matter.

\section{Acknowledgements}

The authors would like to thank to Dean of the Faculty of Geological Engineering Universitas Padjadjaran for financial support in this writing and publication. The authors also like to express gratitude to co-author and colleagues of the Geological Engineering Faculty Universitas Padjadjaran for assistance during field observation and analysis process. 
Proceeding of the $5^{\text {th }}$ International Conference of Geological Engineering Faculty, Vol. 1, Issue 1, 2020, pp. 1-9

\section{References}

Akers WH (1972) Planktonic Foraminifera and Biostratigraphy of Some Neogene Formations, Northern Florida and Atlantic Coastal Plain. Tulane Studies in Geology and Paleontology Vol.9 No. 1-4 https://journals.tulane.edu/tsgp/article/view/573

Bolli H M, Saunders JB et al (1985) Plankton Stratigraphy Volume 1. Cambridge

Isnaniawardhani V (2017) Prinsip dan Aplikasi Biostratigrafi. UNPAD PRESS, Bandung

Lipps JH (1967) Planktonic Foraminifera, Intercontinental Correlation and Age of California Mid-Cenozoic Microfaunal Stages. Journal of Paleontology, 994-999 https://www.jstor.org/stable/1302171?seq=1

Postuma JA (1971) Manual of Planktonic Foraminifera. Elsevier Publishing Company, Amsterdam

Tandean IN (2019) Geologi Daerah Parakanmanggu Kecamatan Parigi, Kabupaten Ciamis, Provinsi Jawa Barat. Faculty of Geological Engineering Universitas Padjadjaran

Van Bemmelen RW et al (1949) The Geology of Indonesia, Volume LA. The Hague Maartinus Nijhoff, Netherland 